\title{
Desain dan Analisis Tegangan Rangka Alat Simulasi Pergerakan Kendali Terbang Menggunakan Metode Elemen Hingga
}

\author{
Ready Kresna Nanda Suprapto ${ }^{1, a)}$, Lasinta Ari Nendra Wibawa ${ }^{2, b)}$ \\ ${ }^{1}$ Politeknik Penerbangan Indonesia Curug (PPI Curug) \\ Jl. Raya PLP Curug, Serdang Wetan, Kec. Legok, Tangerang-Banten, 15820 \\ ${ }^{2}$ Lembaga Penerbangan dan Antariksa Nasional (LAPAN) \\ Jl. Cilauteureun, Cikelet, Garut-Jawa Barat, Indonesia, 44175

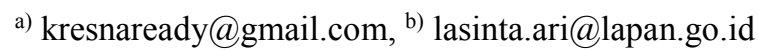

\begin{abstract}
Abstrak
Alat simulasi pergerakan kendali terbang merupakan alat peraga untuk menunjukkan mekanisme kerja dari sayap dan ekor pesawat terbang yang mendekati kenyataan. Alat ini bermanfaat sebagai metode pembelajaran bagi calon pilot sebelum mengendarai sebuah pesawat terbang. Penelitian ini bertujuan untuk merancang dan menganalisis rangka alat simulasi pergerakan kendali terbang dengan menggunakan metode elemen hingga. Analisis statik dilakukan menggunakan perangkat lunak SolidWorks 2017. Material rangka yang digunakan yaitu baja ASTM A36 dan ASTM A500 (square hollow section) dengan ukuran $50 \times 50 \times 1,2 \mathrm{~mm}$ dan $40 \times 40 \times 1 \mathrm{~mm}$. Beban yang digunakan yaitu $375,25 \mathrm{~kg}$ yang merupakan beban sayap dan ekor pesawat. Hasil analisis menunjukkan rancangan rangka aman untuk menahan beban dinamis menggunakan baja ukuran 50 × 50 × 1,2 mm. Hal ini karena material ASTM A36 dan ASTM A500 untuk ukuran 50 × 50 × 1,2 mm memiliki faktor keamanan berturut-turut 2,162 dan 2,724.
\end{abstract}

Kata kunci: analisis statik, metode elemen hingga, simulasi kendali terbang, solidworks

\begin{abstract}
The flight control movement simulation tool is a visual aid to show the working mechanism of an airplane wing and tail close to reality. This tool is useful as a learning method for aspiring pilots before driving an airplane. The study aims to design and analyze a flight control movement simulation frame using the finite element method. Static analysis was performed using SolidWorks 2017 software. The frame material used was ASTM A36 and ASTM 500 steel (square hollow section) with sizes of $50 \times 50 \times 1.2 \mathrm{~mm}$ and $40 \times 40 \times 1 \mathrm{~mm}$. The load used is $375.25 \mathrm{~kg}$, which is the weight of the aircraft's wing and tail. The analysis results show that a safe frame design to withstand dynamic loads uses $50 \times 50 \times 1.2$ mm steel. The ASTM A36 and ASTM A500 materials for sizes $50 \times 50 \times 1.2 \mathrm{~mm}$ have a safety factor of 2.162 and 2.724 , respectively.
\end{abstract}

Keywords: static analysis, finite element method, flight control simulation, solidworks

\section{PENDAHULUAN}

Dunia penerbangan di Indonesia semakin berkembang pesat. Hal ini ditandai dengan hadirnya lembaga pendidikan berwawasan kedirgantaraan di berbagai daerah. Kondisi ini diharapkan dapat meningkatkan kualitas sumber daya manusia di bidang industri dirgantara.

Materi pendidikan yang diberikan lembaga pendidikan kedirgantaraan umumnya meliputi teknik perbaikan pesawat, perancangan pesawat, dan sistem kendali terbang. Materi yang diberikan mayoritas berupa permainan simulasi pesawat terbang. Hanya saja simulasi ini memiliki kelemahan karena tidak dapat menunjukan mekanisme kerja dari kendali pesawat terbang [1], [2].

Calon pilot dan teknisi pesawat perlu mengetahui bagaimana mekanisme kerja dari kendali pesawat terbang, pergerakan kabel, dan katrol untuk menggerakan sayap pesawat dan ekor pesawat [3]. Kondisi ini yang mendasari pentingnya alat simulasi pegerakan kendali terbang yang berupa modifikasi dari pesawat asli. Hal ini bertujuan agar calon pilot dan teknisi pesawat mengerti bagaimana mekanisme gerak pesawat terbang.

Alat simulasi pergerakan kendali terbang adalah alat peraga untuk menunjukkan mekanisme kerja dari sayap dan ekor pesawat terbang yang mendekati kenyataan. Alat ini bertujuan sebagai metode pembelajaran bagi calon pilot sebelum mengendarai sebuah pesawat terbang.

Beban dari sayap dan ekor pesawat menyebabkan perlu adanya analisis statik pada rangka guna memperoleh desain rangka yang aman digunakan. Analisis statik memainkan peranan penting dalam mendesain suatu rangka karena sebelum membuat struktur yang nyata perlu diketahui parameter yang mempengaruhi rangka 
tersebut. Hasil analisis statik dapat digunakan sebagai prediksi awal untuk mengetahui apakah rangka dapat dipakai pada kondisi aktual.

Perkembangan teknologi telah memudahkan perhitungan analisis rangka dengan sangat akurat menggunakan perangkat lunak berbasis CAD maupun CAE. Beberapa jenis perangkat lunak yang umum digunakan untuk analisis rangka yaitu, SolidWorks, Autodesk Inventor, Catia, dan Ansys [4]-[9].

Penelitian ini bertujuan untuk merancang rangka alat simulasi pergerakan kendali terbang dan melakukan analisis statik menggunakan material dengan standar dan dimensi yang berbeda.

\section{LANDASAN TEORI}

Landasan teori pada penelitian ini akan menjelaskan hal-hal yang berhubungan dengan fokus penelitian, antara lain: gaya pada pesawat terbang, kendali pesawat terbang, macam-macam profil rangka, material, metode elemen hingga, dan hasil simulasi elemen hingga.

\section{A. Gaya pada Pesawat Terbang [10]}

Pesawat dapat terbang karena adanya gaya-gaya yang bekerja pada pesawat terbang. Ada empat gaya yang bekerja pada pesawat terbang, yaitu:

\section{Gaya dorong (thrust)}

Gaya dorong (thrust) menyebabkan pesawat dapat bergerak maju di udara. Gaya ini dapat dihasilkan dari baling-baling pesawat yang digerakkan oleh motor bakar atau gaya dorong yang dihasilkan oleh mesin jet.

\section{Gaya angkat (lift)}

Gaya angkat adalah gaya untuk mengangkat pesawat ke atas. Gaya angkat dihasilkan oleh efek dinamis dari udara yang terjadi pada sayap pesawat. Oleh karena itu, bentuk sayap sangat mempengaruhi kemampuan sayap untuk menghasilkan gaya angkat.

\section{Gaya hambat (drag)}

Gaya yang menghambat pesawat maju ke depan. Gaya ini terjadi karena adanya gangguan aliran udara yang mengenai luas penampang pesawat. Gaya drag timbul karena pesawat bergerak melalui fluida udara yang menyebabkan terjadinya gesekan dengan udara yang dilaluinya.

\section{Gaya berat (weight)}

Gaya ini dihasilkan karena beban pesawat. Gaya berat muncul akibat adanya gaya gravitasi dan bekerja vertikal ke bawah. Gaya berat berlawanan dengan gaya angkat (lift). Untuk dapat terbang, pesawat harus memiliki gaya angkat yang lebih besar daripada gaya berat.

Gambar 1 menunjukkan gaya-gaya yang bekerja pada pesawat terbang.

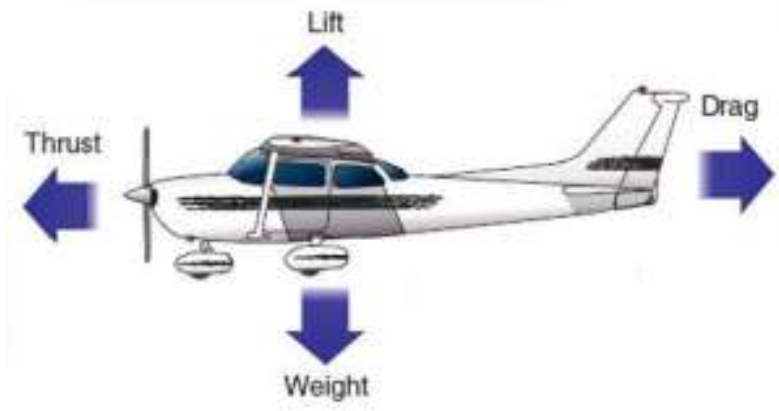

Gambar 1. Gaya-gaya yang Bekerja pada Pesawat Terbang.

\section{B. Kendali Pesawat Terbang [11]}

Sebuah pesawat harus memiliki perangkat kendali (control devices) agar bisa dikendalikan sesuai keinginan dan tujuan penerbangan bisa dilakukan dengan baik. Perangkat kendali pada pesawat dikendalikan oleh pilot dalam sebuah ruang kendali (cockpit).

Pada pesawat terbang terdapat tiga bidang kendali utama, yaitu aileron, elevator, dan rudder. Ketiga bidang kendali tersebut berfungsi untuk mengendalikan pergerakan pesawat terbang, mengendalikan pesawat terbang berdasarkan sumbu rotasinya, dan mengendalikan kestabilan pesawat terbang. Fungsi dari masing-masing kendali terbang, antara lain:

\section{Aileron}

Aileron terletak pada sayap dan digunakan pada saat melakukan gerakan berguling di udara (rolling). Penggerakannya berada pada sumbu longitudinal pesawat. Aileron dikendalikan dengan stick control di dalam cockpit. Jenis kestabilan yang dilakukan aileron adalah untuk menstabilkan secara lateral.

\section{Elevator}

Elevator terletak pada horizontal stabilizer dan merupakan bidang kendali yang berpengaruh pada gerakan pitch. Jenis kestabilan yang dilakukan Elevator adalah menstabilkan secara longitudinal. Elevator yang merupakan bagian dari sirip horisontal di ekor pesawat berfungsi mengendalikan pesawat naik dan turun (updown). Elevator dikendalikan dengan menggunakan stick control yang berada di ruangan cockpit.

\section{Rudder}

Rudder yang merupakan bagian dari sirip vertikal di ekor pesawat mengatur pesawat untuk belok ke kiri dan ke kanan (yaw) yang dibantu oleh Aileron yang terletak di kiri-kanan sayap utama (sayap depan pesawat). Jenis kestabilan yang dilakukan rudder adalah menstabilkan secara directional.

Gambar 2 menunjukkan perangkat kendali dasar dari sebuah pesawat terbang. 


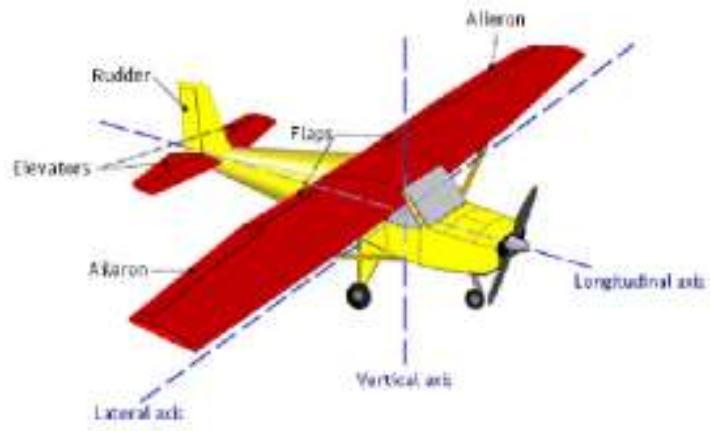

Gambar 2. Perangkat Kendali Dasar Pesawat Terbang.

\section{Macam-macam Profil Rangka (Frame) [12]}

Rangka (frame) adalah komponen terpenting pada sebuah rancangan alat karena berfungsi sebagai penopang beban. Rangka penyusun kendali terbang pesawat terdiri dari lower skin, upper skin, ribs, dan spar. Pada pesawat terbang rangka dibuat seringan mungkin, tetapi tetap memenuhi kekuatan yang sesuai dengan persyaratan. Rangka pesawat juga membutuhkan material yang tahan terhadap karat. Untuk itu pada umumnya pesawat modern menggunakan material komposit, sehingga membuat struktur pesawat ringan namun kuat untuk menahan beban yang bekerja.

Pada alat simulasi pergerakan kendali terbang ini tidak difungsikan untuk terbang seperti halnya pesawat, sehingga alat ini tidak membutuhkan spesifikasi material yang ringan dan tahan akan korosi.

Baja dipilih sebagai material alat ini karena mempunyai sifat yang kuat dan mudah ditemukan di pasar Indonesia. Ada beberapa jenis profil rangka baja yang beredar di pasaran, antara lain:

1. Baja Wide Flange (WF)

Baja Wide Flange yaitu baja yang memiliki kekuatan tekan dan tarik yang tinggi. Baja WF merupakan elemen sempurna untuk menahan tarik serta tekan aksial. Kelebihan lainnya yakni bobotnya tidak terlalu berat walaupun memiliki struktur kepadatan yang tinggi. Baja WF merupakan baja penyangga yang didesain untuk menyangga benda berat. Baja WF memiliki kekuatan yang seimbang dalam kekuatan tarik maupun tekan, sehingga biasanya digunakan untuk berbagai keperluan dalam konstruksi, misalnya konstruksi untuk pembangunan jembatan, gudang, dan gedung. Baja WF dibentuk dengan proses cenai panas (hot rolled). Baja profil WF ditunjukkan pada Gambar 3.

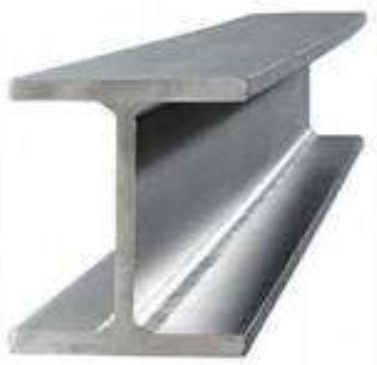

Gambar 3. Baja Profil Wide Flange (WF).

\section{Baja Kanal U (UNP)}

Baja Kanal U atau UNP atau U Channel Steel merupakan salah satu jenis baja yang dibuat sesuai standar Eropa. Baja Kanal U umumnya digunakan sebagai bagian dari pembuatan struktur sebuah bangunan atau industri. Disebut sebagai Baja Kanal U karena bentuk penampang irisannya menyerupai saluran (kanal) berbentuk huruf ' $U$ '.

Besi baja UNP sering digunakan dalam konstruksi baja sebagai penopang atau penyangga utama. Besi UNP juga dapat digunakan sebagai bracing atau penguat pada konstruksi baja untuk bangunan atau jembatan.

Baja UNP tersedia dalam berbagai ukuran. Ukuran tersebut mengikuti ukuran dimensi yang dapat dilihat dari gambar penampangnya. Baja profil Kanal U ditunjukkan pada Gambar 4 berikut ini.

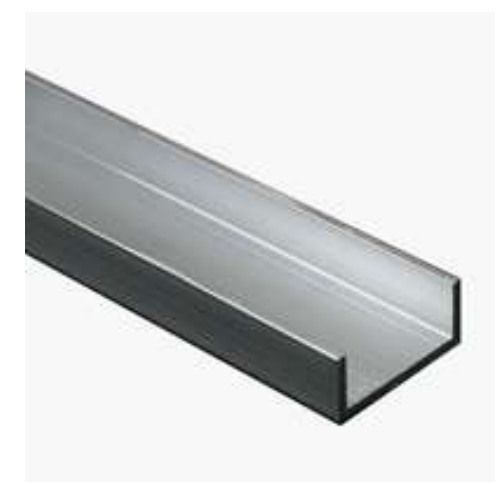

Gambar 4. Baja Profil Kanal U.

\section{Baja Kanal C (CNP)}

Baja ringan kanal $\mathrm{C}$ memiliki bentuk mirip huruf $\mathrm{C}$. Kanal $\mathrm{C}$ biasa digunakan untuk kosntruksi atap atau kuda-kuda. Selain itu juga bisa digunakan sebagai tiang untuk bangunan yang tidak memiliki beban berat, misalnya untuk kanopi. Gambar 5 menunjukkan baja profil Kanal C.

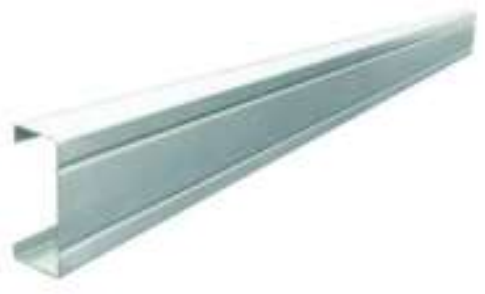

Gambar 5. Baja Profil Kanal C.

\section{Baja Rectangular Hollow Section (RHS)}

Baja Rectangular Hollow Section (RHS) biasa digunakan untuk komponen rangka arsitektur. Baja ini memiliki banyak jenis dan dimensinya. Baja RHS ditunjukkan pada Gambar 6. 


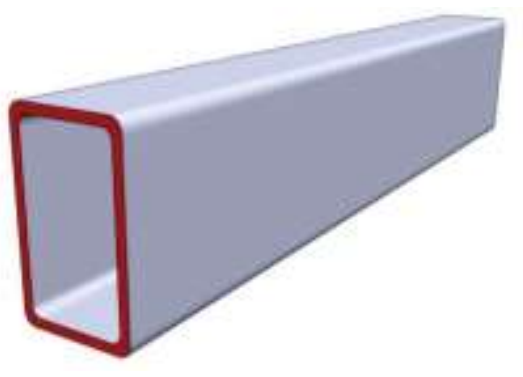

Gambar 6. Baja Profil RHS.

5. Baja Persegi (Square Hollow Section/SHS).

Baja profil persegi atau square hollow section (SHS) yang ditunjukkan pada Gambar 7 merupakan profil baja berdinding tipis yang umum digunakan dalam struktur rangka (structural framing). Struktur baja ringan merupakan struktur baja yang ketebalannya relatif tipis yaitu sekitar 0,3-6,0 $\mathrm{mm}$ dengan rasio lebar terhadap tebal di setiap bagian struktur sangat besar. Struktur baja jenis ini dapat dibuat dari baja lembaran (steel sheets) melalui proses pengerjaan dingin (cold forming) seperti press braking, bending braking atau cold rolling.

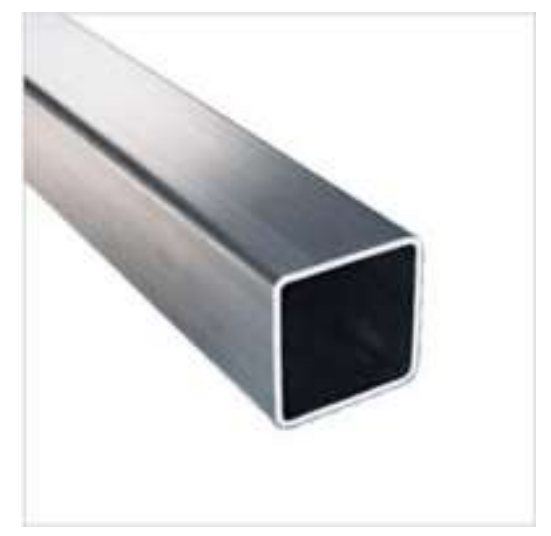

Gambar 7. Baja Profil Persegi (Square Hollow Section/SHS).

\section{Pipa Baja (Steel Pipe)}

Salah satu jenis pipa yang kerap ditemukan di dunia industri adalah pipa dengan bahan baja. Pipa baja sendiri dianggap memiliki kekuatan dan daya tahan yang jauh lebih baik dari bahan pipa lainnya sehingga dapat mengalirkan berbagai fluida yang dianggap ekstrim dan membutuhkan sistem perpipaan yang lebih aman dan dapat diandalkan. Fluida dengan tekanan tinggi layaknya minyak dan gas adalah yang paling sering dialirkan oleh jenis pipa ini.

Pipa baja memiliki dimensi yang beragam dan penggunaannya juga berbeda-beda. Pipa baja merupakan jenis pipa yang memiliki profil berbentuk silinder yang biasanya digunakan untuk mengalirkan fluida cair maupun gas. Pipa baja dapat diklasifikasikan menjadi beberapa jenis yaitu pipa air, pipa minyak, pipa gas, pipa lumpur, dan pipa uap. Profil pipa baja ditunjukkan pada Gambar 8.

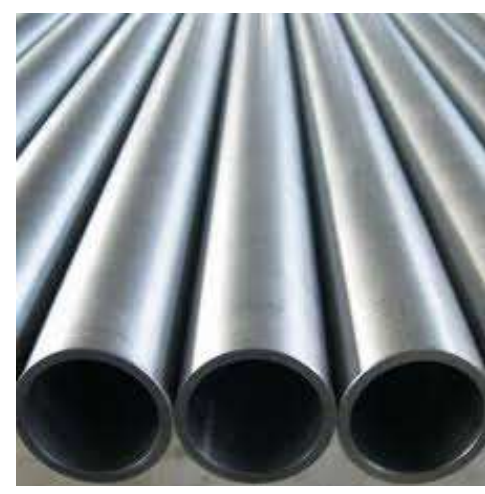

Gambar 8. Profil Pipa Baja.

Pada penelitian ini digunakan baja square hollow section (SHS) berukuran $40 \times 40 \times 1,0$ dan $50 \times 50 \times 1,2$ $\mathrm{mm}$.

\section{Material}

Pemilihan suatu material untuk bagian rangka adalah salah satu hal yang perlu dipertimbangkan dalam merancang suatu desain.

Dalam merancang sebuah alat atau rangka, telah ditetapkan prosedur pemilihan material yang akan digunakan. Pemilihan material harus sesuai dengan kondisi aplikasinya. Oleh karena itu, perlu diperhatikan dalam memilih jenis material, antara lain [13]:

1. Kekuatan (strength) dari material yaitu kemampuan material untuk menahan beban tanpa adanya kerusakan.

2. Elastisitas (elasticity) merupakan kemampuan material untuk mampu kembali ke bentuk aslinya, setelah gaya dihilangkan. Sifat ini sangat penting bagi suatu rangka yang mengalami beban dinamis atau beban yang berubah-ubah terhadap waktu.

3. Kekakuan (stiffness) ini berarti sejauh mana material mampu menahan deformasi atau defleksi pada gaya yang diterapkan.

4. Keuletan (ductility) ini merupakan kemampuan suatu bahan untuk diubah bentuknya tanpa kehilangan kekuatan atau kerusakan. Sifat ulet ini sangat diperlukan untuk material yang mengalami beban secara tiba-tiba.

Baja adalah bahan yang sangat sering digunakan dalam pembuatan rangka karena mempunyai sifat yang kaku, kuat, memiliki daya tahan yang tinggi, dan mudah dibentuk.

\section{E. SolidWorks [5]}

SolidWorks adalah perangkat lunak desain berbantuan komputer (CAD) yang dimiliki oleh Dassault System. SolidWorks menggunakan prinsip desain parametrik dan menghasilkan tiga jenis file yang saling berhubungan: komponen, perakitan, dan gambar. Oleh karena itu, modifikasi apa pun pada salah satu dari tiga file ini akan tercermin pada dua file lainnya.

SolidWorks merupakan salah perangkat lunak desain parametrik yang mudah digunakan dan sangat popular di kalangan desainer. SolidWorks menawarkan kemudahan 
dalam mengedit desain pada tahap mana pun dalam proses desain. Grafik RealView memungkinkan pengguna untuk memvisualisasikan desain dalam waktu nyata sementara PhotoView 360 dapat membuat rendering dan animasi foto realistis yang canggih. SolidWorks dapat menunjukkan setiap bagian desain dengan detail, melihat properti massa yang akurat, dan memeriksa masalah untuk mencari desain yang optimal sehingga tidak perlu membuat/memproduksi produk sebelum terjadi kesalahan, menghemat waktu dan uang, serta mengurangi jumlah prototipe yang diperlukan. Hal ini tentu dapat mempercepat seluruh proses desain seperti yang Anda ketahui dan meningkatkan produktivitas.

\section{F. Metode Elemen Hingga (finite element method) [14]}

Finite Element Method (FEM) adalah prosedur numeris yang dipakai dalam menyelesaikan permasalahan di bidang rekayasa, seperti menganalisis tegangan pada rangka. Metode ini digunakan untuk menyelesaikan masalah rekayasa yang tidak bisa diselesaikan secara nyata atau exact solution.

Metoda elemen hingga banyak digunakan untuk mendapatkan penyelesaian pendekatan dari masalahmasalah fisik, khususnya yang berhubungan dengan suatu kontinum. Sebagai contoh adalah masalah perpindahan panas (heat transfer), mekanika fluida (fluid mechanic). dan mekanika benda padat (solid mechanic). Metode elemen hingga mengkombinasikan beberapa konsep matematika untuk mendapatkan suatu sistem persamaan linier atau non linier.

Metode elemen hingga pada dasarnya dibagi menjadi lima langkah penyelesaian yaitu:

1. Diskritisasi daerah/kontinum yang ditinjau. Hal ini meliputi penentuan lokasi dan koordinat-koordinat serta penomoran dari titik-titik nodal (node points).

2. Menentukan persamaan interpolasi dan menyatakan persamaan ini di dalam harga-harga dari titik-titik nodal yang tidak diketahui untuk tiap-tiap elemen.

3. Menyusun sistem persamaan untuk seluruh elemen dengan menggunakan metode Galerkin atau metode Energi Potensial.

4. Menyelesaikan sistem persamaan untuk mendapatkan harga-harga parameter dari setiap titik nodal.

5. Menghitung besaran-besaran yang akan ditentukan. Besaran-besaran ini pada umumnya merupakan turunan dari parameter yaitu komponen-komponen tegangan, rambatan panas, dan kecepatan aliran.

Jumlah persamaan menggunakan metode elemen hingga pada umumnya adalah cukup besar sehingga perhitungan dengan metode ini perlu dilakukan dengan menggunakan komputer. Hal ini untuk menghemat waktu dan biaya serta agar hasil yang didapat bisa akurat.

Jadi, prinsip utama dari metode elemen hingga adalah membagi suatu benda menjadi beberapa bagian (biasanya berbentuk jala) dengan jumlah terbatas. Bagian-bagian ini akan berbentuk segitiga atau segiempat linear yang disebut dengan elemen, tiap-tiap elemen akan disatukan dengan nodal (node). Untuk lebih jelasnya bisa dilihat pada Gambar 9 berikut ini.

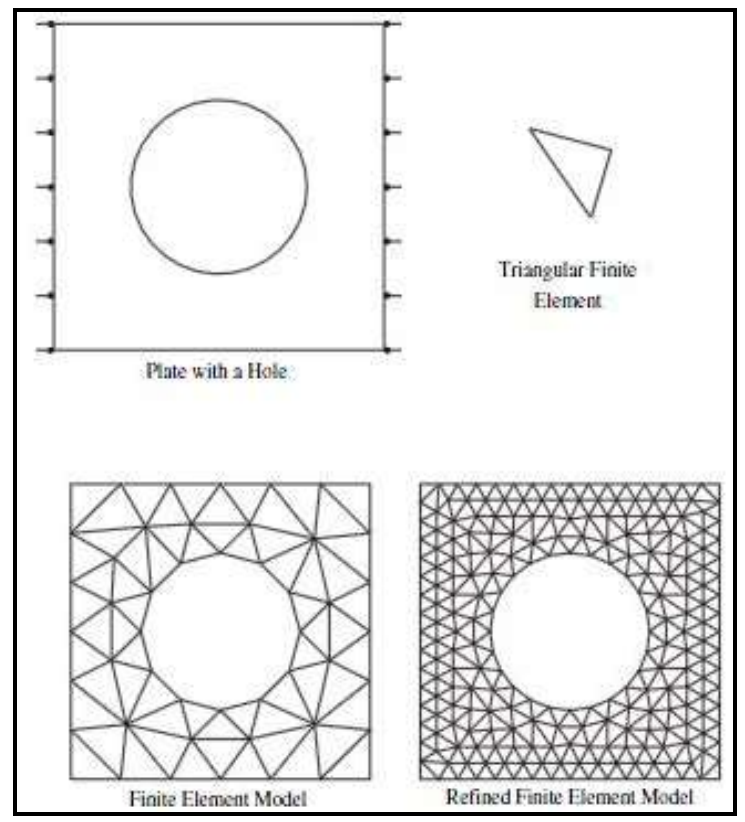

Gambar 9. Meshing Pada Plat [15].

\section{G. Hasil Simulasi Elemen Hingga}

Hasil simulasi elemen hingga menggunakan perangkat lunak SolidWorks menghasilkan beberapa variabel, yaitu:

1. Tegangan (stress)

Tegangan merupakan perbandingan antara gaya yang bekerja pada benda dengan luas penampang benda. Secara matematis dapat dituliskan:

$\sigma=\frac{F}{A}$

Dimana:

$$
\begin{array}{ll}
\sigma & =\text { Tegangan }(\mathrm{Pa}) \\
\mathrm{F} & =\text { Gaya }(\mathrm{N}) \\
\mathrm{A} & =\text { Luas Penampang }\left(\mathrm{m}^{2}\right)
\end{array}
$$

Analisis dari tegangan yang bekerja pada suatu struktur sangat penting karena pemilihan bahan dan desain rangka harus didasari dengan nilai maksimum dari suatu tegangan yang bekerja.

Salah satu jenis tegangan yang perlu dianalisis yaitu tegangan statis. Tegangan Statis (static stress) merupakan tegangan akibat pembebanan yang dilakukan terhadap suatu komponen dimana beban yang diberikan diam dengan besar nilai yang tetap atau konstan. Contoh beban statis adalah beban yang diberikan pada sebuah struktur karena beban mati pada sebuah bangunan.

Tegangan von Mises adalah tegangan tarik uniaksial yang dapat menghasilkan energi distorsi yang sama dengan yang dihasilkan oleh kombinasi tegangan yang bekerja. Tegangan von Mises digunakan untuk memprediksi hasil material yang mengalami pembebanan kompleks.

Kriteria von Mises menganggap bahwa peluluhan material ulet dimulai ketika invarian kedua dari tegangan 
deviasi mencapai nilai kritis. Kriteria ini adalah bagian dari teori plastisitas yang paling baik diterapkan pada bahan ulet, seperti beberapa logam. Sebelum menghasilkan, respons material dapat diasumsikan sebagai perilaku elastis nonlinier, viskoelastik, atau linier. Tegangan von Mises disebut juga sebagai tegangan setara (equivalent).

Material dapat dikatakan mulai luluh ketika tegangan von Mises mencapai nilai yang disebut kekuatan luluh (yield strength). Tegangan von Mises digunakan untuk memprediksi hasil material yang mengalami pembebanan kompleks dari hasil uji tarik uniaksial.

\section{Deformasi (displacement)}

Deformasi yaitu perubahan fisik dari suatu benda dikarenakan adanya gaya atau beban yang diterima. Deformasi juga dibagi menjadi dua jenis yaitu deformasi elastis dan deformasi plastis. Deformasi elastis merupakan perubahan fisik dari suatu benda akibat adanya gaya atau beban dan akan kembali ke bentuk awal saat gaya atau beban ditiadakan. Sementara itu deformasi plastis merupakan perubahan fisik suatu benda secara tetap, walaupun gaya atau beban sudah dihilangkan. Dalam perancangan suatu alat tentu saja yang digunakan adalah deformasi elastis sebab tegangan maksimum dibatasi di bawah yield strength [16].

\section{Faktor keamanan (safety factor)}

Faktor keamanan (safety factor) adalah faktor yang sering digunakan dalam mengevaluasi keamanan dari suatu elemen. Nilai faktor keamanan dapat dinyatakan aman jika mempunyai nilai di atas 1 (satu). Faktor keamanan berfungsi untuk menghindari suatu kegagalan dan menentukan layak atau tidaknya alat yang dibuat untuk dioperasikan. Ada beberapa faktor yang dapat mempengaruhi faktor keamanan, antara lain [13]:

1. Jenis material yang digunakan

2. Variasi ukuran dari komponen yang diuji

3. Jenis beban yang bekerja

4. Akibat dari perlakuan panas terhadap komponen

5. Akibat dari umur dan perawatan komponen

6. Keamanan manusia yang secara keseluruhan harus diperhatikan

7. Akibat dari waktu dan lingkungan dimana alat tersebut digunakan

Faktor keamanan (safety factor) dirumuskan dengan persamaan sebagai berikut:

$$
S F=\frac{\sigma \text { yield strength }}{\sigma \text { maximum von misses stress }}
$$

Faktor keamanan digunakan untuk mengevaluasi keamanan komponen atau struktur meskipun dimensi yang digunakan minimum. Faktor keamanan dapat didasarkan pada salah satu batas tegangan tarik maksimum atau tegangan luluh dari material [17]. Kekuatan luluh adalah tegangan minimum saat material mulai kehilangan sifat elastisnya, yaitu sifat material untuk kembali ke bentuk semula saat beban atau gaya dihilangkan. Kekuatan tarik maksimum adalah tegangan maksimum yang mampu dicapai suatu material sebelum patah. Faktor keamanan pada kekuatan luluh bertujuan untuk mencegah deformasi yang merugikan, sedangkan faktor keamanan pada kekuatan tarik maksimum bertujuan mencegah keruntuhan [18]. Faktor keamanan kurang dari 1 (satu) menunjukkan kegagalan permanen dari sebuah desain [14]. Pada penelitian ini, faktor keamanan berdasarkan pada kekuatan luluh (yield strength) karena rangka alat simulasi kendali terbang merupakan komponen yang akan digunakan secara berulang-ulang.

Dobrovolsky dalam buku Machine Elements: A Textbook membagi faktor keamanan berdasarkan beban, yaitu [19]:
1. Beban statis
$: 1,25-2$
2. Beban dinamis
$: 2-3$.
3. Beban kejut
$: 3-5$.

\section{METODE PENELITIAN}

Pada pembuatan dan perancangan alat ini, dilakukan metodologi penelitian seperti pada diagram alir pada Gambar 10.

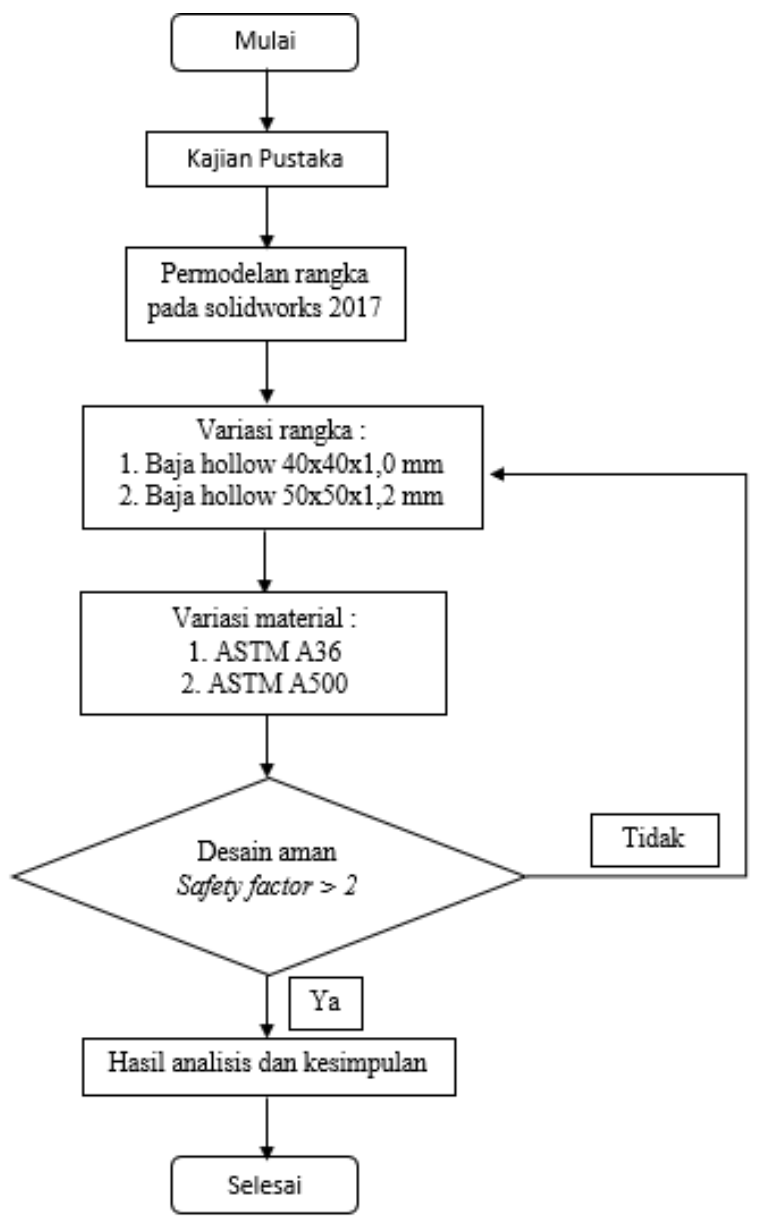

Gambar 10. Diagram Alir

Material yang dirancang untuk rangka alat simulasi pergerakan kendali terbang yaitu material baja square hollow section ASTM A36 yang mempunyai kekuatan luluh (yield strength) hingga $250 \mathrm{MPa}$ dan ASTM 500 
yang mempunyai kekuatan luluh (yield strength) hingga $310 \mathrm{MPa}$ [20], [21]. Sifat mekanik material secara detail ditunjukkan pada Tabel 1. Dimensi baja square hollow section dengan variabel ukuran ISO Standard 50 x 50 x1,2 mm dan 40 x 40 x 1,0 mm ditunjukan pada Gambar 11 .

Tabel 1. Sifat Mekanik Material ASTM A36 dan A500.

\begin{tabular}{cccc}
\hline No. & Parameter & ASTM A36 & ASTM A500 \\
\hline 1 & Density & $75850 \mathrm{~kg} / \mathrm{m}^{3}$ & $75850 \mathrm{~kg} / \mathrm{m}^{3}$ \\
2 & Yield strength & $250 \mathrm{MPa}$ & $315 \mathrm{MPa}$ \\
3 & Tensile strength & $310 \mathrm{MPa}$ & $400 \mathrm{MPa}$ \\
4 & Shear modulus & $79,3 \mathrm{GPa}$ & $80 \mathrm{GPa}$ \\
\hline
\end{tabular}
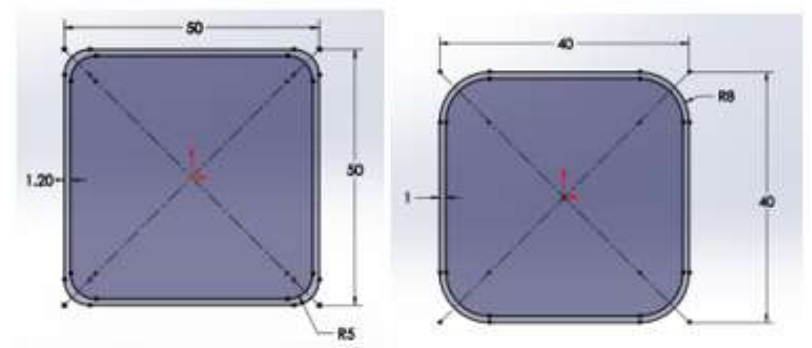

Gambar 11. Dimensi Baja Square Hollow Section (dalam $\mathrm{mm})$.

Untuk pembuatan desain 3D dan analisis tegangan, penelitian ini menggunakan perangkat lunak (software) SolidWorks 2017. SolidWorks adalah perangkat lunak pendukung yang mampu membantu untuk proses pembuatan desain suatu rancangan 2 Dimensi maupun 3 Dimensi [22]. Dimensi rangka menyesuaikan pada dimensi sayap dan ekor pesawat, yang telah diukur dengan metode pengukuran manual pada sayap dan ekor pesawat Fokker-27, seperti yang ditunjukan pada Gambar 12.

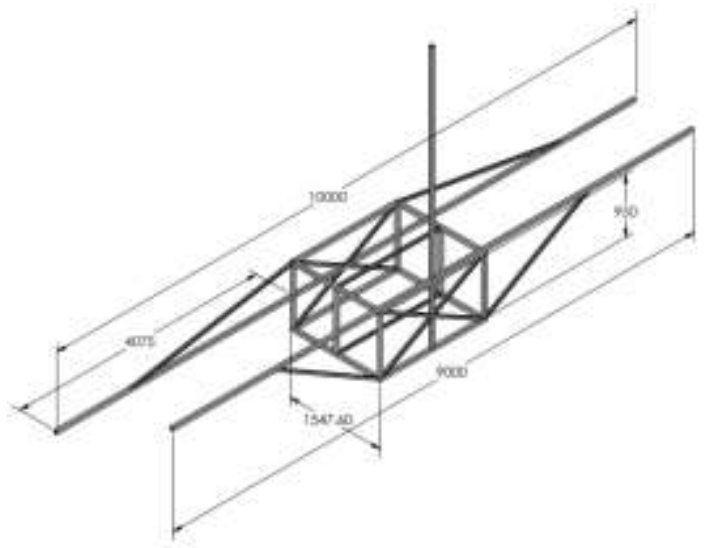

Gambar 12. Dimensi Alat Simulasi Pergerakan Kendali Terbang (dalam $\mathrm{mm}$ ).

Simulasi dilakukan dengan memberikan beban pada rangka sesuai dengan berat sayap dan ekor pesawat pesawat seperti yang ditunjukan pada Gambar 13. Data beban sayap dan ekor pesawat didapatkan dengan metode pengukuran manual serta menggunakan fitur mass properties pada perangkat lunak SolidWorks 2017. Fitur mass properties ini dapat mengetahui beban komponen sesuai dengan jenis material yang digunakan [23].

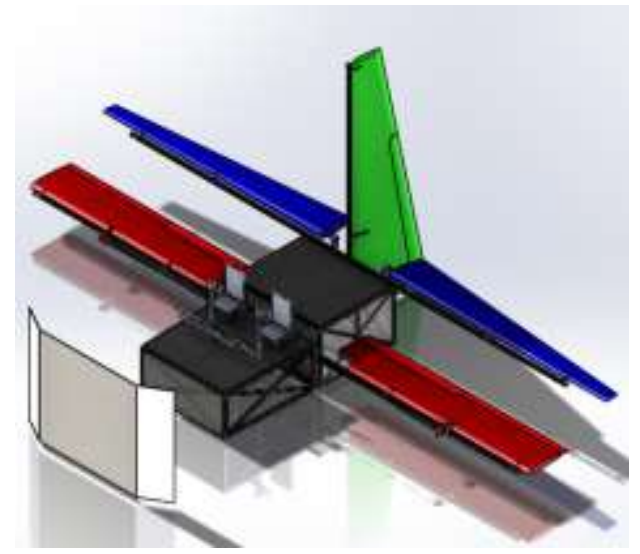

Gambar 13. Desain Alat Simulasi Pegerakan Kendali Terbang.

Guna menentukan batasan (constraint) pada perangkat lunak SolidWorks 2017, digunakan fitur fixed constraint ditempatkan pada bagian yang diasumsikan diam yaitu pada alas rangka.

Analisis tegangan (stress) pada SolidWorks 2017 menggunakan metode elemen hingga. Metode Elemen Hingga (Finite Element Method) merupakan metode yang digunakan untuk mendapatkan hasil perhitungan yang akurat dengan membagi obyek menjadi bentuk jala (mesh) [14]. Dengan adanya analisis tegangan ini diharapkan mendapatkan hasil tegangan von misses, dimana tegangan von misses ini sering digunakan untuk mengetahui safety factor dari suatu desain.

Kondisi batas (boundary condition) analisis tegangan menggunakan perangkat lunak SolidWorks 2017 secara lengkap dapat dilihat dari Tabel 2 berikut ini.

Tabel 2. Parameter Analisis Tegangan.

\begin{tabular}{|c|c|c|}
\hline No & Tipe Simulasi & Single Point \\
\hline 1 & Ukuran baja & $\begin{array}{c}50 \times 50 \times 1,2 \mathrm{~mm} \text { dan } \\
40 \times 40 \times 1,0 \mathrm{~mm}\end{array}$ \\
\hline 2 & Percepatan gravitasi & $9,812 \mathrm{~m} / \mathrm{s}^{2}$ \\
\hline 3 & Ukuran elemen & $1 \mathrm{~mm}$ \\
\hline 4 & $\begin{array}{l}\text { Jumlah node rangka } 50 \times \\
50 \times 1,2 \mathrm{~mm}\end{array}$ & 130970 \\
\hline 5 & $\begin{array}{c}\text { Jumlah elemen rangka } 50 \\
\times 50 \times 1,2 \mathrm{~mm}\end{array}$ & 65508 \\
\hline 6 & $\begin{array}{l}\text { Jumlah node rangka } 40 \times \\
\qquad 40 \times 1,0 \mathrm{~mm}\end{array}$ & 130793 \\
\hline 7 & $\begin{array}{c}\text { Jumlah elemen rangka } 40 \\
\times 40 \times 1,0 \mathrm{~mm}\end{array}$ & 65420 \\
\hline 6 & Safety factor & $\begin{array}{c}\text { Berdasarkan yield } \\
\text { strength }\end{array}$ \\
\hline 7 & $\begin{array}{l}\text { Berat sayap pesawat } \\
\text { (Aileron })\end{array}$ & $\begin{array}{l}202,11 \mathrm{~kg} \text { atau } \\
1.982,02 \mathrm{~N}\end{array}$ \\
\hline 8 & $\begin{array}{l}\text { Berat ekor pesawat } \\
\text { (Elevator })\end{array}$ & $\begin{array}{c}173,14 \mathrm{~kg} \text { atau } \\
3.679,94 \mathrm{~N}\end{array}$ \\
\hline
\end{tabular}


Asumsi pada saat melakukan analisis tegangan von misses menggunakan software CAD, yaitu [24]:

1. Setelah batas luluh (yield strength), sifat komponen material tetap linier

2. Perubahan ukuran dari material sangat kecil dibandingkan dengan ukuran komponen keseluruhan.

3. Komponen bersifat kaku dan ulet.

4. Kontak pada setiap rangka diasumsikan kontak berikat (bonded contact). Artinya, permukaan antar rangka kaku satu sama lain. Kontak ini dapat berupa sambungan las atau adhesif.

\section{HASIL DAN PEMBAHASAN}

Hasil simulasi tegangan von Mises rangka alat simulasi pergerakan kendali terbang terhadap variasi ukuran baja ditunjukkan pada Gambar 14 dan Gambar 15. Tegangan von Mises maksimal untuk baja ukuran 40 x 40 x 1,0 mm dan 50 × 50 × 1,2 mm berturut-turut sebesar 235,8 MPa dan 115,6 MPa. Tegangan maksimal masih berada di bawah kekuatan luluh (yield strength) material ASTM A36 dan A500 secara berturut-turut, yaitu sebesar 250 MPa dan $310 \mathrm{MPa}$.

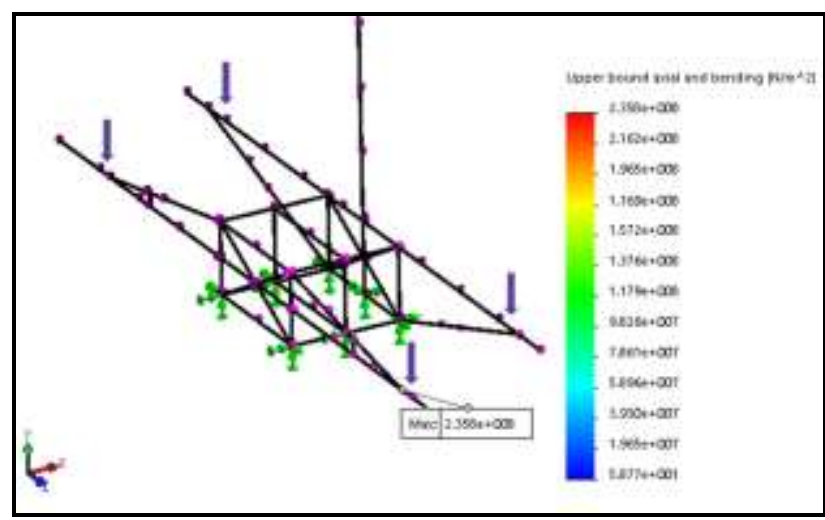

Gambar 14. Tegangan Von Misses Rangka Baja dengan Ukuran 40 × 40 × $1,0 \mathrm{~mm}$.

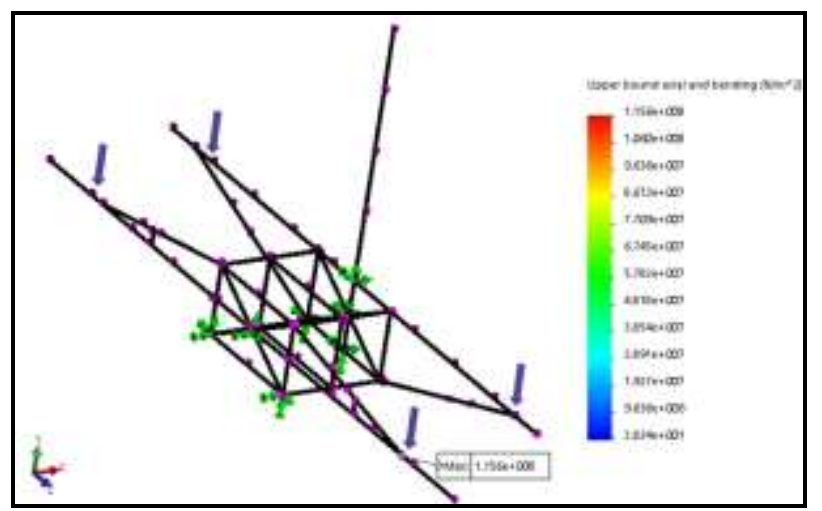

Gambar 15. Tegangan Von Misses Rangka Baja dengan Ukuran 50 × 50 × 1,2 mm.

Hasil dari nilai deformasi (displacement) material terhadap variasi beban ditunjukan pada Gambar 16 dan Gambar 17. Nilai deformasi maksimal rangka simulasi pergerakan kendali terbang terhadap ukuran baja $40 \times 40$ x $1,0 \mathrm{~mm}$ dan $50 \times 50 \times 1,2 \mathrm{~mm}$ berturut-turut sebesar
$5,89 \mathrm{~mm}$ dan $2,71 \mathrm{~mm}$. Nilai deformasi ini relatif kecil [7].

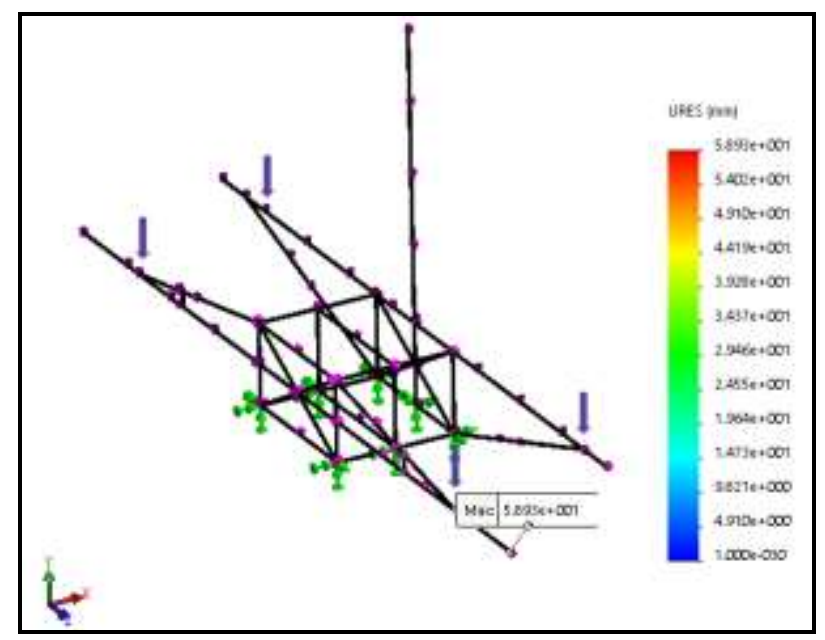

Gambar 16. Deformasi Rangka Baja dengan Ukuran 40 x 40 x $1,0 \mathrm{~mm}$.

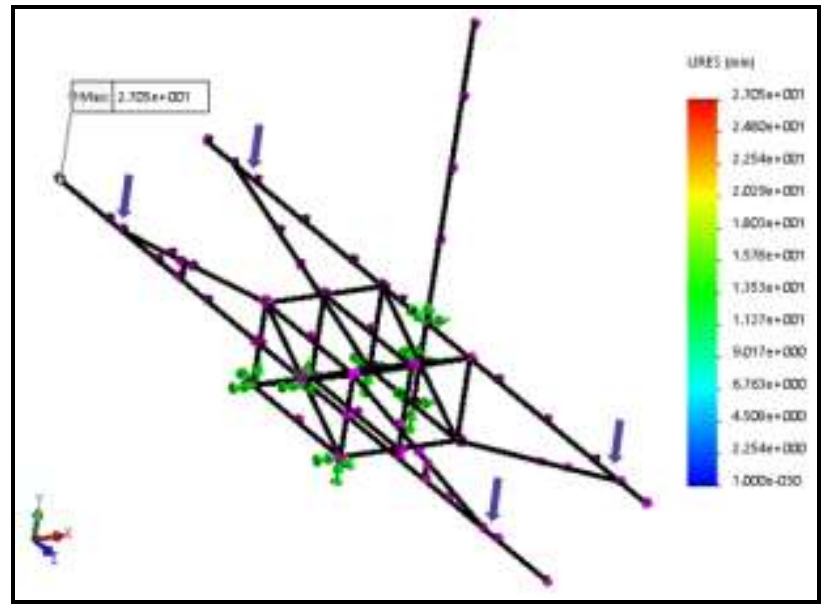

Gambar 17. Deformasi Rangka Baja dengan Ukuran 50 x 50 x $1,2 \mathrm{~mm}$

Hasil analisis nilai safety factor (faktor keamanan) material terhadap variasi ukuran dan jenis material ditunjukkan pada Gambar 18, Gambar 19, Gambar 20, dan Gambar 21. Nilai faktor keamanan minimum pada rangka baja square hollow section ukuran 40 x 40 × 1,0 mm menggunakan material ASTM A36 dan ASTM A500 berturut-turut sebesar 1,060 dan 1,336 (Gambar 18 dan Gambar 19). Sedangkan nilai faktor keamanan minimum pada rangka baja square hollow section ukuran 50 x $50 \mathrm{x}$ $1,2 \mathrm{~mm}$ menggunakan material ASTM A36 dan ASTM A500 berturut-turut sebesar 2,162 dan 2,724 (Gambar 20 dan Gambar 21). 


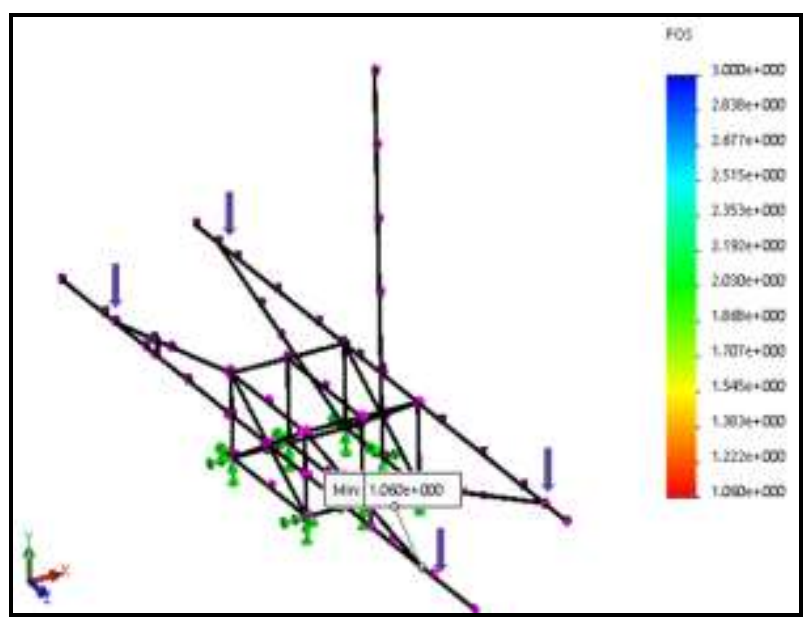

Gambar 18. Faktor Keamanan Rangka Baja Square Hollow Section dengan Ukuran $40 \times 40 \times 1,0 \mathrm{~mm}$ dengan Material ASTM A36.

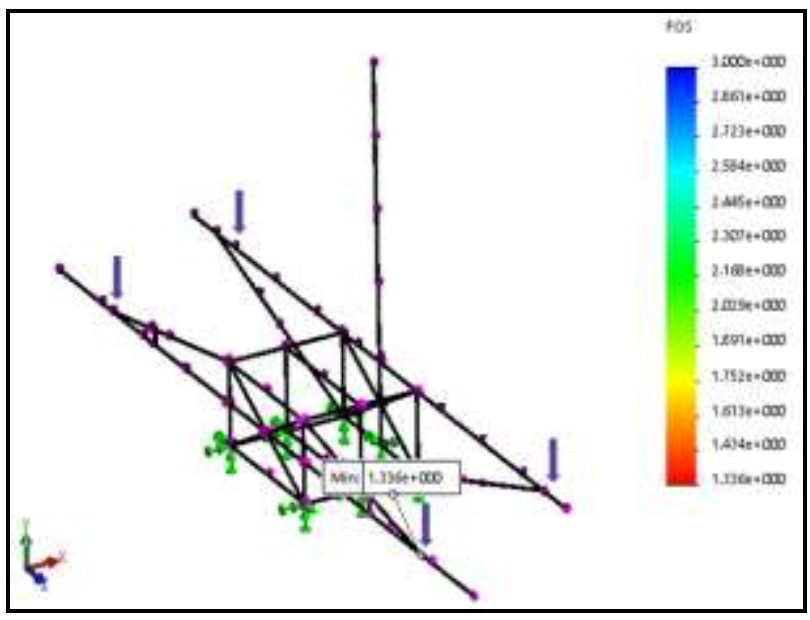

Gambar 19. Faktor Keamanan Rangka Baja Square Hollow Section dengan Ukuran $40 \times 40 \times 1,0 \mathrm{~mm}$ dengan Material ASTM A500.

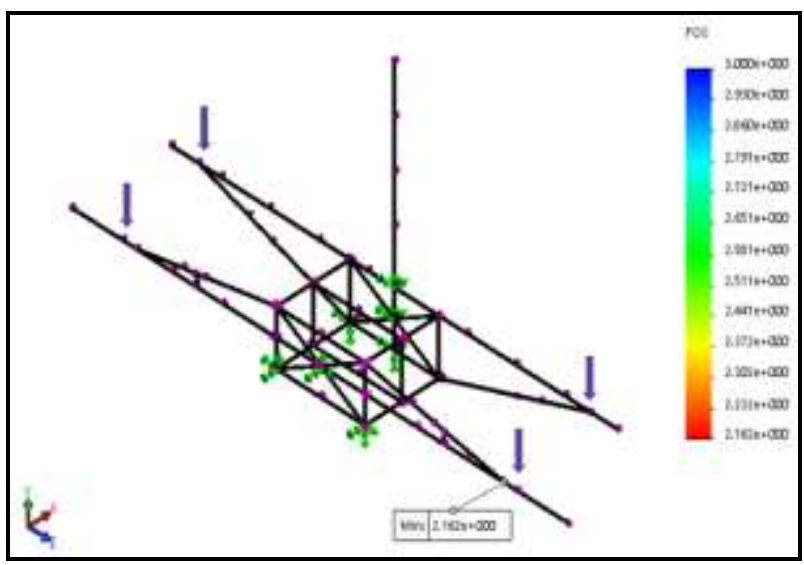

Gambar 20. Faktor Keamanan Rangka Baja Square Hollow Section dengan Ukuran 50 × 50 × 1,2 mm dengan Material ASTM A36.

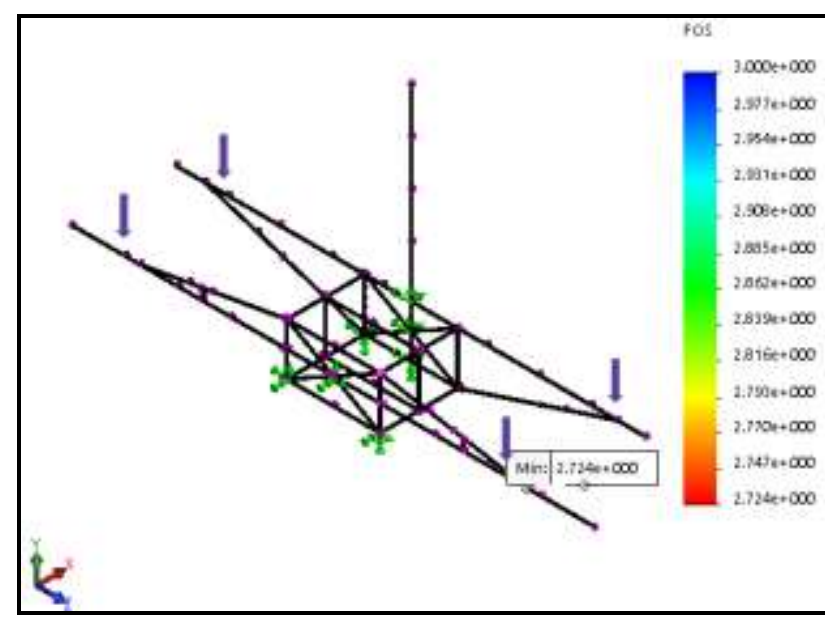

Gambar 21. Faktor Keamanan Rangka Baja Square Hollow Section dengan Ukuran 50 × 50 × 1,2 mm dengan Material ASTM A500.

Hasil simulasi elemen hingga menggunakan perangkat lunak SolidWorks secara lengkap ditunjukkan pada Tabel 3. Besar nilai faktor keamanan untuk baja berukuran $40 \mathrm{x}$ $40 \times 1,0 \mathrm{~mm}$ tidak memasuki standar yang dipersyaratkan pada komponen yang mampu menahan beban dinamis. Beban dinamis adalah beban yang terjadi secara tiba-tiba pada rangka yang dapat berubah-ubah seiring waktu. Beban dinamis perlu diperhitungkan mengingat kerja dari kendali terbang yang menggerakan sayap dan ekor pesawat. Untuk memasuki persyaratan beban dinamis, faktor keamanan harus bernilai 2-3

Pada rangka baja ukuran 50 × 50 × 1,2 mm dinyatakan aman untuk menahan beban dinamis. Hal ini berdasarkan nilai faktor keamanan yang diperoleh rangka 50 x 50 x 1,2 mm dengan material ASTM A36 dan ASTM A500 secara berturut-turut sebesar 2,162 dan 2,724.

Tabel 3. Hasil Simulasi Elemen Hingga.

\begin{tabular}{cccc}
\hline Material & $\begin{array}{c}\text { Tegangan } \\
\text { Von Mises } \\
\text { maksimum } \\
(\mathrm{MPa})\end{array}$ & $\begin{array}{c}\text { Deformasi } \\
(\mathrm{mm})\end{array}$ & $\begin{array}{c}\text { Faktor } \\
\text { keamanan }\end{array}$ \\
\hline $\begin{array}{c}40 \times 40 \times 1,0 \mathrm{~mm} \\
(\text { ASTM A36) }\end{array}$ & 235,8 & 5,89 & 1,060 \\
$\begin{array}{c}40 \times 40 \times 1,0 \mathrm{~mm} \\
(\text { ASTM A500) }\end{array}$ & 235,8 & 5,89 & 1,336 \\
$\begin{array}{c}50 \times 50 \times 1,2 \mathrm{~mm} \\
(\text { ASTM A36) }\end{array}$ & 115,6 & 2,71 & 2,162 \\
$\begin{array}{c}50 \times 50 \times 1,2 \mathrm{~mm} \\
(\text { ASTM A500) }\end{array}$ & 115,6 & 2,71 & 2,724 \\
\hline
\end{tabular}

\section{KESIMPULAN}

Berdasarkan hasil analisis rangka dengan menggunakan perangkat lunak SolidWorks 2017 pada rangka baja ukuran $50 \times 50 \times 1,2 \mathrm{~mm}$ dan $40 \times 40 \times 1,0$ $\mathrm{mm}$ dengan jenis material ASTM A36 dan A500 diperoleh kesimpulan sebagai berikut:

1. Hasil tegangan von Mises maksimum (maximum von misses stress) pada besi ukuran $40 \times 40 \times 1,0 \mathrm{~mm}$ sebesar 235,8 $\mathrm{MPa}$. Dengan menggunakan material 
ASTM A36 dan ASTM A500 didapatkan nilai safety factor secara berturut-turut yaitu 1,060 dan 1,336, Nilai faktor keamanan ini hanya aman untuk menahan beban statis.

2. Hasil tegangan von Mises maksimum pada baja ukuran 50 x 50 x 1,2 mm sebesar 115,6 MPa. Dengan menggunakan material ASTM A36 dan ASTM A500 didapatkan nilai safety factor secara berturut-turut yaitu 2,162 dan 2,724. Nilai faktor keamanan ini dapat dinyatakan aman untuk menahan beban dinamis.

\section{REFERENSI}

[1] A. Hidayat and B. D. Adiputra, Perancangan game flight simulator N219 yang dikendalikan dengan perangkat smartphone android melalui media Wi-Fi," Compiler, vol. 4, no. 1, 2015, pp. 9-14.

[2] O. M. Fajarianto, Pemanfaatan flight simulator untuk meningkatkan kinerja pilot," J. Educ., vol. 3, no. 1, 2018, pp. 75-80.

[3] F. A. A. (FAA)/Aviation S. \& A. (ASA), Aviation maintenance technician, Handbook: Airframe. 2018.

[4] M. Awwaluddin, Analisa kekuatan rangka sepeda listrik menggunakan software solidworks, vol. 3, no. 1, 2019, pp. 5-16.

[5] A. Sasmito, Disain kekuatan sambungan joop pillar dan floor bearer pada struktur rangka bus menggunakan solidworks, Simetris, vol. 9, no. 1, 2018, pp. 657-670.

[6] L. A. N. Wibawa, Desain dan analisis kekuatan rangka meja kerja (workbench) Balai LAPAN Garut Menggunakan Metode Elemen Hingga, JTM-ITI (Jurnal Tek. Mesin ITI), vol. 3, no. 1, 2019, pp. 13-17.

[7] L. A. N. Wibawa and K. Diharjo, Pengaruh beban terhadap prediksi umur fatik rangka meja kerja balai LAPAN Garut menggunakan Ansys Workbench, J. Tek. Mesin ITI, vol. 4, no. 2, 2020, pp. 57.

[8] L. A. N. Wibawa, Desain dan analisis kekuatan rangka lemari perkakas di Balai LAPAN Garut menggunakan metode elemen hingga, Mach. J. Tek. Mesin, vol. 5, no. 2, 2019, pp. 45-50.

[9] N. Wahyudi and Y. A. Fahrudi, Studi eksperimen rancang bangun rangka jenis ladder frame pada kendaraan sport, JEECAE (Journal Electr. Electron. Control. Automot. Eng., vol. 1, no. 1, 2017, pp. 71-75.

[10] M. Mulyadi, Analisis aerodinamika pada sayap pesawat terbang dengan menggunakan software berbasis computational fluid dynamics (CFD), 2015.

[11] S. Aryanto, N. D. Retnowati, and B. Basir, Simulator kendali pesawat terbang extra $300 \mathrm{~L}$ berbasis 3D dengan metode simulation game, Compiler, vol. 3, no. 1, 2014, pp. 91-100.
[12] H. Husnah, N. E. Darfia, and F. Hidayat, Analisis struktur rangka baja ringan dan baja berat (Wf) dengan metode bricscad, Siklus J. Tek. Sipil, vol. 5, no. 2, 2019, pp. 87-96.

[13] F. Hardiputra, A. Djafar, and Sulistijono, Perancangan as roda troli pemanjat tangga berdasarkan analisis tegangan dan faktor keamanan shaft design for stair-climbing hand truck based on, in SNITT- Politeknik Negeri Balikpapan, 2018, pp. 312-316.

[14] L. A. N. Wibawa and K. Diharjo, Desain, pemilihan material, dan faktor keamanan stasiun pengisian gawai menggunakan metode elemen hingga, J. Teknol., vol. 11, no. 2, 2019. pp. 97102.

[15] T. Fish, Jacob; Belytschko, A First Course in Finite Elements. 2007.

[16] L. A. N. Wibawa, Pengaruh pemilihan material terhadap kekuatan rangka main landing gear untuk pesawat UAV, J. Teknol. dan Terap. Bisnis, vol. 2, no. 1, 2019, pp. 48-52.

[17] L. A. N. Wibawa, Pengaruh susunan dan jumlah lubang baut terhadap kekuatan rangka main landing gear untuk pesawat UAV, Flywheel J. Tek. Mesin Untirta, vol. 5, no. 1, 2019 pp. 46-50.

[18] L. A. N. Wibawa, K. Diharjo, W. W. Raharjo, and B. H. Jihad, Pengaruh ketebalan cap dan tekanan internal terhadap tegangan von mises silinder berdinding tebal untuk tabung motor roket, Teknik, vol. 41, no. 2, 2020, pp. 111-118.

[19] V. Dobrovolsky and K. Zablonsky, Machine elements : a textbook. Moscow: Peace Publisher, 1978.

[20] H. U. Sajid and R. Kiran, Influence of high stress triaxiality on mechanical strength of ASTM A36, ASTM A572 and ASTM A992 steels, Constr. Build. Mater., vol. 176, 2018, pp. 129-134.

[21] A. P. Kumar, C. H. Siva, and R. Krishna, Sensitivity analysis of tig welding parameters for astm- 500 grade b weldments, vol. 6 , no. 1, 2015, pp. $1-10$.

[22] A. Sucipta, A. Saggaff, and S. Muliawan, Analisa pola keruntuhan konstruksi rangka atap dengan menggunakan profil baja ringan, J. Tek. Sipil dan Lingkung., vol. 1, no. 1, 2013, pp. 13-21.

[23] E. Prasetyo, R. Hermawan, M. N. I. Ridho, I. I. Hajar, H. Hariri, and E. A. Pane, Analisis kekuatan rangka pada mesin Transverse Ducting Flange (TDF) menggunakan software solidworks, Rekayasa, vol. 13, no. 3, 2020, pp. 299-306.

[24] L. A. N. Wibawa, Desain dan analisis tegangan struktur crane kapasitas 10 Ton menggunakan metode elemen hingga, J. Muara Sains, Teknol. Kedokt. dan Ilmu Kesehat., vol. 4, no. 2, 2020, pp. 201. 